\title{
Metode Barbeau Test dalam Menilai Keutuhan Arteri Radialis Pascaintervensi Koroner Perkutan
}

\author{
Nurhusna $^{1}$, F. Sri Susilaningsih ${ }^{2}$, Purwo Suwigjo ${ }^{3}$ \\ ${ }^{1}$ Fakultas Keperawatan Universitas Jambi, ${ }^{2}$ Fakultas Keperawatan Universitas Padjadjaran, \\ ${ }^{3}$ RSUP Dr Hasan Sadikin \\ E-mail: nrhusna81@gmail.com
}

\begin{abstract}
Abstrak
Radial artery occlusion merupakan salah satu komplikasi vaskular post kateterisasi jantung trans radial. Kompresi lokal menggunakan alat kompresi setelah tindakan kateterisasi jantung trans radial dapat menurunkan angka kejadian komplikasi vaskular Radial Artery Occlusion (RAO). Penelitian ini bertujuan untuk mengetahui perbandingan antara metode Barbeau test dan metode pengamatan klinik dalam menilai keutuhan arteri radialis selama proses kompresi pada pasien post prosedur kateterisasi jantung trans radial. Penelitian ini merupakan penelitian kuantitatif dengan desain studi komparatif. Subjek penelitian adalah 20 pasien yang menjalani prosedur kateterisasi jantung dengan akses arteri radialis. Pengukuran dilakukan secara bertahap menit ke-15 dan setelah tiga jam menggunakan alat kompresi stepty-p. Uji komparasi menggunakan uji McNemar. Data univariat dianalisis menggunakan distribusi frekuensi. Hasil uji statistik menunjukkan ada perbedaan penilaian keutuhan arteri radialis antara metode Barbeau test dengan metode pengamatan klinik pada menit ke-15 $(p=0.035)$ dan ke-30 $(p=0.035)$. Namun secara keseluruhan hasil uji statistik menunjukkan tidak ada perbedaan yang bermakna dalam menilai kepatenan arteri pada setiap waktu pengamatan dari kedua metode.
\end{abstract}

Kata kunci: Arteri radialis, Barbeau test, kateterisasi jantung, keutuhan, pengamatan klinik.

\section{The Barbeau Test Method in Examining The Patency of Radial Artery during Compression Post Cardiac Catheterization Procedure}

\begin{abstract}
Radial artery occlusion is one of the trans radial vascular complications post cardiac catheterization. The local compression using compression methods after cardiac catheterization can be reduced the vascular complication such as radial artery occlusion (RAO). This research was conducted to determine the comparison between the Barbeau test method and the clinical observation method carried out by the researcher in order to examine the patency of radial artery during compression, post procedure cardiac catheterization at the Angiography Coroner Unit and the Cardiac Intensive Care Unit, Hasan Sadikin Bandung General Hospital, Indonesia. This research was a quantitative research using the comparative study design. The subjects were 20 patients who took cardiac catheterization procedure using radial artery access and checked in pairs. The measurement divided into two periods: the fifteenth minute and the third hour using the stepty-p compression tool. The statistical test used the McNemar test to analyze the comparison, and the single variable data were analyzed using the distribution frequency. There were a significant difference in radial artery evaluation during compression period between two methods, in which at the first fifteen minutes $(p=0.035)$ and the first thirty minutes $(p=0.035)$, respectively. Overall, the result shows that there were no significant difference in comparison of two methods.
\end{abstract}

Key words: Barbeau test, cardiac catheterization, clinical observation, patency, radial artery. 
Nurhusna: Metode Berbeau Test dalam Menilai Keutuhan Arteri Radialis

\section{Pendahuluan}

Penyakit jantung koroner merupakan suatu kondisi dimana terjadi penyempitan, penyumbatan, atau kelainan yang terjadi pada pembuluh darah koroner. Penyempitan atau penyumbatan ini dapat menghentikan aliran darah ke otot jantung yang sering ditandai dengan rasa nyeri. Kondisi lebih parah dapat mengakibatkan kemampuan jantung dalam memompa darah akan hilang, sehingga sistem kontrol irama jantung terganggu dan selanjutnya bisa menyebabkan kematian (Falk, Shah, \& Fuster, 2005). Kateterisasi Jantung (Coronary Angiography) merupakan salah satu prosedur diagnostik bersifat invasif yang dilakukan dengan tujuan untuk mendiagnosis penyakit jantung koroner. Tindakan kateterisasi jantung ini dapat menilai kondisi struktur dan fungsi dari pembuluh darah koroner (Mitinach \& Hollinger, 2005).

Pilihan akses perifer yang dapat digunakan dalam prosedur Coronary Angiography (kateterisasi jantung) yaitu dapat melalui arteri femoralis, arteri radialis, atau arteri brakhialis. Arteri femoralis menjadi salah satu arteri yang paling sering digunakan sebagai akses, namun hasil dari beberapa penelitian menyebutkan bahwa tingginya kejadian risiko komplikasi vaskular yang menyertai penggunaan akses femoralis ini (Biancari, dkk., 2010), seperti hematom pada area penusukan (superficial) dan perdarahan retroperitoneal (Berry, Kelly, Cobbe, \& Eteiba, 2004). Akses melalui arteri femoralis juga sering dihubungkan dengan peningkatan kejadian nyeri punggung, retensi urin, penambahan waktu untuk ambulasi, dan neuropati (Cooper, dkk., 1999).

Akses vaskular melalui arteri radialis dalam 20 tahun terakhir menunjukkan hasil yang lebih baik dan aman dibandingkan akses melalui arteri femoralis. Achouh, dkk., (2009) dalam penelitiannya membandingkan penggunaan akses femoralis dan radialis dalam pelaksanaan prosedur kateterisasi jantung mengungkapkan bahwa penggunaan arteri radialis dalam kateterisasi jantung terbukti mengurangi komplikasi perdarahan sebanyak $73 \%$ insiden kematian sebanyak $30 \%$, infark miokard dan kejadian strok dibandingkan dengan akses femoralis.
Radial Artery Occlusion (RAO) atau disebut juga oklusi arteri radialis merupakan komplikasi pascaprosedur kateterisasijantung melalui akses arteri radialis. Radial Artery Occlusion bersifat akut dan dapat menjadi permanen. Estimasi kejadian berkisar 1-10\% (Gilchrist, 2009). Radial Artery Occlusion terjadi sebagai akibat dari proses trombosis (pembentukan trombus) di arteri radialis yang mengalami gangguan kepatenan aliran darah setelah prosedur tindakan kateterisasi jantung. Pemasangan sheath kateter selama prosedur intervensi dapat memicu kerusakan di lapisan endothelial pembuluh darah arteri, dan merangsang aktivasi proses trombosis (Stella, dkk., 1997; Nagai, dkk., 1999).

Beberapa faktor teridentifikasi sebagai prediktor terjadinya RAO, yaitu faktorfaktor selama prosedur tindakan (procedural factors) seperti ukuran diameter arteri yang lebih kecil daripada diameter terluar sheath (Zhou, dkk., 2007; Nagai, dkk., 1999; Yoo, dkk., 2005; Spaulding, dkk.,1996), penusukan yang berulang (Yonetsu, dkk., 2010), dan penggunaan antikoagulan yang tidak adekuat (Zhou, dkk., 2007). Faktor yang lain yaitu faktor setelah prosedur tindakan (postprocedural factors) seperti occlusive hemostatic compression atau pencapaian hemostasis dengan kompresi yang terlalu kuat sehingga menyumbat aliran darah arteri (Zhou, dkk., 2007; Sanmartin, dkk., 2007; Pancholy. 2009). Hasil penelitian menunjukkan bahwa strategi nonocclusive hemostasis dapat dianggap sebagai strategi yang paling bermakna dalam menurunkan kejadian RAO (Pancholy \& Patel, 2012). Nonocclusive hemostasis adalah pencapaian hemostasis tanpa menyebabkan terjadinya oklusi. Pencapaian pada kondisi hemostasis dalam prosedur kateterisasi jantung dilakukan segera setelah pelepasan sheath kateter atau pascaprosedur tindakan kateterisasi. Pencapaian hemostasis ini dilakukan dengan teknik kompresi atau memberikan tekanan eksternal pada arteri radialis yang menjadi akses vaskular.

Proses kompresi dilakukan secara manual dengan pemberian tekanan langsung, ataupun menggunakan alat kompresi. Alat kompresi yang digunakan bekerja secara unilateral dengan tetap mempertahankan aliran darah vena (venous blood flow) dan aliran darah 
Nurhusna: Metode Berbeau Test dalam Menilai Keutuhan Arteri Radialis

bagian distal (distal blood flow). Apabila proses kompresi tidak memerhatikan kedua aspek tersebut, seperti tindakan kompresi yang cenderung memberikan tekanan yang terlalu kuat sehingga dapat menutup aliran darah di arteri radialis baik secara total maupun parsial. Terdapat lima jenis alat kompresi yang biasa digunakan untuk akses arteri radialis, yaitu: tourniquet, alat kompresi mekanik, hidrophilic wound dressing, dan pressure dressing, serta manual dressing. Belum ada hasil studi yang menjelaskan jenis alat kompresi yang lebih efektif yang mampu memberikan tekanan yang tepat dan tidak menimbulkan oklusi di arteri radialis. Oleh sebab itu, beberapa penelitian menyarankan untuk melakukan pemantauan secara ketat selama proses kompresi dengan mendeteksi gejala timbulnya komplikasi RAO sedini mungkin, sehingga dapat dilakukan langkahlangkah penanganan secara cepat (Uhleman, dkk., 2012).

Deteksi terhadap RAO dapat dilakukan dengan penilaian gejala klinik (Allen's test), Barbeau test, dan tes yang menggunakan doppler (Brancati, dkk., 2012). Deteksi yang menggunakan pengamatan klinik yaitu deteksi yang menilai kejadian RAO berdasarkan temuan tanda dan gejala iskemik. Penggunaan metode ini kurang objektif, artinya metode ini tidak mampu secara tepat menilai terjadinya RAO. Hasil studi menunjukkan bahwa RAO kadang bersifat asimtomatis atau tanpa gejala, hal ini disebabkan karena adanya pengaruh mekanisme dual sirkulasi pada radialis dan ulnaris. Insiden kasus kejadian RAO dalam 24 jam setelah prosedur kateterisasi jantung, yaitu satu dari 500 kasus berdasarkan gejala klinik munculnya tanda iskemik, yang mana gejala iskemik baru muncul ketika terjadi hambatan aliran total, mengikuti buruknya mekanisme dual sirkulasi (Sfeir, Khoury, Khoury, Rustum \& Ghabash, 1996; Slogoff, Keats, \& Arlund, 1993). Metode Barbeau test dan metode penilaian menggunakan doppler ultrasound dianggap lebih objektif dalam mendeteksi terjadinya RAO. Doppler ultrasounography dan metode Barbeau test dapat mendeteksi gejala RAO berdasarkan penilaian aliran darah dalam arteri radialis dengan mekanisme dual sirkulasi. Metode yang paling baik yaitu menggunakan doppler, namun beberapa hasil studi menunjukkan bahwa metode Barbeau test memiliki keakuratan yang sebanding dengan doppler dalam menilai karekteristik aliran collateral artery ulnaris dan kepatenan aliran di radialis. Metode doppler jarang digunakan karena metode ini membutuhkan biaya dan keahlian, sehingga metode yang sering digunakan dalam mendeteksi kejadian RAO yaitu metode pengamatan klinik dan Barbeau test.

Metode Barbeau test dapat digunakan oleh perawat selama proses perawatan pasien pascaprosedur kateterisasi melalui akses radial, metode Berbeau test ini digunakan dalam mendeteksi secara dini dan menilai terhadap terjadinya penurunan aliran darah serta oklusi di arteri radialis selama proses kompresi yang menggunakan alat kompresi. Saat ini baru terdapat dua studi penelitian yang menggunakan metode Barbeau test selama kompresi, yaitu penelitian Sanmarti menggunakan alat kompresi manual dressing (Sanmartin, dkk., 2007) dan penelitian Pancholy (2009) menggunakan alat kompresi mekanik TR-Band. Hasil dari kedua penelitian ini menunjukkan bahwa metode Barbeau test mampu mengenali gejala gangguan kepatenan arteri radialis selama proses kompresi secara cepat dan akurat, sehingga hal tersebut dapat meminimalisir terjadinya RAO. Penelitian terkait penggunaan stepty- $p$ selama proses kompresi pascaprosedur kateterisasi jantung dilakukan oleh Tse, dkk. (2006) di Cina, penelitian ini tidak menggunakan metode Barbeau test dalam penilaian keutuhan arteri radialis selama kompresi, melainkan menggunakan metode pengamatan klinik. Hasil dari penelitian ini melaporkan bahwa tidak ditemukannya kasus oklusi di arteri radialis pascaprosedur kateterisasi jantung. Begitu juga di RSUP. dr Hasan Sadikin, tepatnya di ruang tindakan angiografi koroner, kasus kejadian RAO tidak pernah ditemukan berdasarkan penilaian pengamatan klinik dan perawatan post prosedur kateterisasi jantung dengan akses arteri radialis menggunakan alat kompresi stepty- $p$, sebaliknya metode Barbeau test belum pernah dipakai, dan diuji pada ruangan tersebut. Tujuan penelitian ini adalah untuk mengetahui perbedaan metode Barbeau test dan metode pengamatan klinik dalam menilai keutuhan arteri radialis selama kompresi pada pasien post prosedur 
Nurhusna: Metode Berbeau Test dalam Menilai Keutuhan Arteri Radialis

kateterisasi jantung trans radialis.

\section{Metode Penelitian}

Penelitian ini merupakan penelitian kuantitatif yang menggunakan desain studi komparatif dengan pendekatan rancangan studi potong lintang. Pengambilan data dilakukan secara prospektif. Sampel dalam penelitian ini adalah pasien yang telah dilakukan prosedur kateterisasi jantung (angiografi koroner atau percutaneus coronary intervention) dengan akses arteri radialis dan menggunakan alat kompresi stepty-p, di Ruang Angiografi Koroner dan Cardiac Intensive Care Unit (CICU) RSUP dr. Hasan Sadikin.

Penelitian ini dilakukan pada tanggal 7 Juli hingga 27 Juli 2013, dengan kriteria inklusi: pasien dengan masalah sindrom koroner akut yang dilakukan intervensi angiografi koroner dan percutaneus coronary intervention (PCI) menggunakan sheath berukuran $5 \mathrm{~F}$, pasien dengan pemeriksaan Barbeau test normal sebelum prosedur kateterisasi jantung, pasien dengan pemeriksaan Barbeau test normal setelah prosedur kateterisasi jantung atau pasien sebelum alat kompresi dipasang, dan pasien yang mendapatkan terapi antikoagulan jenis heparin atau enoxavarin dengan dosis standar 2500-5000 IU selama prosedur kateterisasi jantung. Penentuan besar sampel penelitian ini menggunakan uji hipotesis perbedaan dua mean dependen atau paired sample (Ariawan, 1998). Sampel dalam penelitian ini adalah 20 orang responden yang diuji secara berpasangan.

Teknik pengumpulan data yang digunakan pada penelitian ini dengan cara pengukuran dan pengamatan. Penelitian ini menggunakan dua orang pengamat atau penilai yang melakukan pengukuran pada pasien yang sama dan pada waktu yang sama, namun menggunakan metode pengukuran berbeda. Pengamat pertama yaitu peneliti sendiri akan melakukan pengumpulan data menggunakan metode Barbeau test, sedangkan pengamat kedua adalah perawat di ruangan yang melakukan pengumpulan data menggunakan metode pengamatan klinik. Hasil dari pengukuran tersebut dicatat pada lembar observasi. Pengambilan data dilakukan selama periode pemakaian alat kompresi perban hemostasis stepty- $p$ (alat kompresi dipasang selama 3 jam), terbagi dalam beberapa tahapan. Setiap tahapannya menggunakan penilaian yang sama dari tiap metode dalam menentukan keutuhan arteri radialis. Tahapan pengukurannya dimulai setelah alat kompresi dipasang, yaitu: setiap 15 menit pada satu jam pertama, dilanjutkan dengan setiap 30 menit pada jam kedua, dan 60 menit berikutnya pada jam ketiga.

Penilaian keutuhan arteri radialis dengan metode Barbeau test dilakukan dengan cara memasang klem sensor alat pulse oksimeter pada ibu jari dari tangan yang digunakan sebagai akses radial pemasangan kateter jantung yang sedang dipasang alat kompresi perban hemostasis. Penilaian tersebut dilakukan selama dua menit, menit pertama mencatat munculnya gambaran pulse oksymetry yaitu saturasi oksigen, dan munculnya gambaran dari pletysmography disaat sensor dipasang. Setelah gambaran pulse oxymetry terlihat terekam, dilanjutkan dengan memberikan tekanan pada arteri ulnaris selama 30 detik, mencatat perubahan yang terjadi pada pulse oksymetry dan pletysmography. Hilangnya gambaran kedua komponen ini menandakan adanya gangguan keutuhan arteri radialis.

Penilaian keutuhan arteri radialis dengan metode pengamatan klinik dilakukan dengan cara memeriksa secara inspeksi adanya tanda dan gejala iskemik pada tangan yang terpasang alat kompresi, yang kemudian dibandingkan dengan tangan yang tidak terpasang alat. Tanda dan gejala yang diamati seperti: perubahan warna kulit telapak tangan yang menjadi pucat atau sianosis, hilangnya sensasi atau kesemutan, pemeriksaan capilary refill kurang dari dua detik, dan hilangnya pulsasi arteri radialis yang dilakukan dengan perabaan. Temuan salah satu dari gejala yang muncul tersebut menunjukkan adanya gangguan keutuhan arteri radialis. Hasil penilaian kemudian didokumentasikan pada lembar observasi. Instrumen yang digunakan dalam penelitian ini adalah lembar observasi penilaian keutuhan arteri radialis berdasarkan metode pengamatan klinik dan metode Barbeau test. Metode Barbeau test menggunakan alat ukur pulse oxymeter yang sudah dilakukan uji validitas dan uji reliabilitas. 
Nurhusna: Metode Berbeau Test dalam Menilai Keutuhan Arteri Radialis

Tabel 1 Karekteristik Subjek Penelitian $(n=20)$

\begin{tabular}{lcc|}
\hline \multicolumn{1}{c}{ Karekteristik } & Frekuensi & Persentase \\
\hline Usia (dalam tahun) & (f) & \% \\
Dewasa Awal (<45) & 1 & 5 \\
Dewasa Pertengahan ( 45-59) & 6 & 30 \\
Usia Lanjut ( $\geq 60)$ & 13 & 65 \\
Jenis Kelamin & & 85 \\
Laki-Laki & 17 & 15 \\
Perempuan & 3 & 45 \\
Indeks Massa Tubuh (IMT) & & 35 \\
Normal (18,50-24,99) & 9 & 20 \\
Berat Badan Lebih ( $\geq 25)$ & 7 & \\
Obesitas ( $\geq 30)$ & 4 & 55 \\
Jenis Tindakan Kateterisasi & & 45 \\
Diagnostik Angiografi Koroner & 11 & 30 \\
Percutaneous Coronary Intervention & 9 & \\
Antikoagulan & & \\
Heparin & 14 & \\
Heparin Plus & 6 & \\
\hline
\end{tabular}

\section{Hasil Penelitian}

Distribusi frekuensi karekteristik subjek penelitian digambarkan berdasarkan usia, jenis kelamin, indeks massa tubuh (IMT), dan tindakan kateterisasi. Karekteristik subjek penelitian ini disajikan pada tabel.1.

Berdasarkan tabel 1 dapat terlihat bahwa proporsi subjek penelitian yang mendapatkan intervensi kateterisasi jantung melalui akses arteri radialis dengan menggunakan alat kompresi stepty- $p$ pada penelitian ini sebagian besar adalah laki-laki (85\%), dan mayoritas berada pada usia lanjut (65\%). Hasil penelitian ini juga menunjukkan bahwa sebagian besar responden memiliki indeks massa tubuh (IMT) yang normal $(45 \%)$ dan hanya sebagian kecil $(20 \%)$ yang obesitas.

Hasil penelitian juga menunjukkan jenis tindakan kateterisasi jantung melalui akses arteri radialis pada penelitian ini sebagian besar adalah tindakan angiografi koroner $(55 \%)$. Berkaitan dengan jenis antikoagulan yang digunakan selama prosedur tindakan kateterisasi jantung, hasil penelitian ini menunjukkan bahwa antikoagulan jenis heparin lebih banyak digunakan selama prosedur $(70 \%)$ dibandingkan dengan heparin plus. Terapi heparin plus yaitu pemberian heparin jenis enoxavarin (lovenox) dengan tambahan plavix (clopidogrel).

1) Penilaian Keutuhan Arteri Radialis berdasarkan Metode Barbeau Test pada Subjek Penelitian

Tabel 2 terdapat hasil penilaian keutuhan arteri radialis pada subjek penelitian berdasarkan penilaian dengan metode Barbeau test. Penilaian gangguan keutuhan aliran darah arteri selama kompresi pada subjek penelitian dinilai negatif dengan Barbeau test berdasarkan tidak adanya pulsasi, saturasi oksigen dan hilangnya gelombang pletysmography pada alat pulse oxymeter yang dipasang pada ibu jari pasien.

Hasil menunjukkan bahwa berdasarkan penilaian dengan metode Barbeau test kondisi arteri radialis subjek penelitian pada praprosedur kateterisasi jantung seluruhnya $(100 \%)$ berada dalam kondisi baik atau paten. Gangguan keutuhan arteri radialis telah terjadi dari menit awal hingga menit akhir proses hemostasis. Hasil studi menunjukkan proporsi terjadinya gangguan keutuhan arteri radialis pada subjek penelitian bervariasi di 
Nurhusna: Metode Berbeau Test dalam Menilai Keutuhan Arteri Radialis

Tabel 2 Penilaian Patensi Arteri Radialis Selama Kompresi dengan Metode Barbeau Test pada Subjek Penelitian $(\mathbf{n}=\mathbf{2 0})$

\begin{tabular}{|c|c|c|}
\hline \multirow[t]{2}{*}{ Waktu Penilaian } & Frekuensi & Persentase \\
\hline & (f) & $(\%)$ \\
\hline \multicolumn{3}{|l|}{ Pre Prosedur Kateterisasi } \\
\hline Positif & 20 & 100,0 \\
\hline Negatif & 0 & 0,0 \\
\hline \multicolumn{3}{|c|}{ Selama Pemakaian Alat Kompresi (stepty- $p$ ) } \\
\hline \multicolumn{3}{|l|}{15 (menit) } \\
\hline Positif & 13 & 65,0 \\
\hline Negatif & 7 & 35,0 \\
\hline \multicolumn{3}{|l|}{30 (menit) } \\
\hline Positif & 14 & 70,0 \\
\hline Negatif & 6 & 30,0 \\
\hline \multicolumn{3}{|l|}{ 45(menit) } \\
\hline Positif & 16 & 80,0 \\
\hline Negatif & 4 & 20,0 \\
\hline \multicolumn{3}{|l|}{60 (menit) } \\
\hline Positif & 16 & 80,0 \\
\hline Negatif & 4 & 20,0 \\
\hline \multicolumn{3}{|l|}{90 (menit) } \\
\hline Positif & 18 & 80,0 \\
\hline Negatif & 2 & 10,0 \\
\hline \multicolumn{3}{|l|}{120 (menit) } \\
\hline Positif & 16 & 80,0 \\
\hline Negatif & 4 & 20,0 \\
\hline \multicolumn{3}{|l|}{180 (menit) } \\
\hline Positif & 15 & 75,0 \\
\hline Negatif & 5 & 25,0 \\
\hline
\end{tabular}

tiap waktu pengamatan, terjadi pada $35 \%$ di menit ke- $15,30 \%$ di menit ke-30, cenderung menurun di menit ke-45 dan ke-60 menjadi $20 \%$, dan terus menurun menjadi $10 \%$ di menit ke-90, meningkat kembali di menit 120 menjadi $20 \%$ hingga $25 \%$ setelah 3 jam proses kompresi.

Hasil studi dapat disimpulkan bahwa berdasarkan penilaian keutuhan arteri radialis dengan metode Barbeau test selama proses kompresi menggunakan stepty- $p$ terjadi gangguan keutuhan arteri radialis pada subjek penelitian. Gangguan keutuhan ini terjadi sejak awal setelah alat kompresi dipasang hingga akhir proses kompresi. Persentase terjadinya gangguan keutuhan bervariasi, terjadi hampir pada sebagian besar responden pada awal kompresi (35\%), cenderung menurun pada menit berikutnya hingga menit akhir kompresi menjadi $25 \%$.

2) Penilaian Keutuhan Arteri Radialis berdasarkan Metode Pengamatan Klinik pada Subjek Penelitian

Penilaian keutuhan arteri radialis dengan metode pengamatan klinik pada subjek penelitian disajikan pada tabel 3 .

Penilaian pada keutuhan arteri radialis berdasarkan metode pengamatan klinik dinyatakan negatif bila ditemukan salah satu dari gejala klinik, seperti: perubahan warna kulit yang pucat sampai kebiruan (sianosis), 
Nurhusna: Metode Berbeau Test dalam Menilai Keutuhan Arteri Radialis

Tabel 3 Penilaian Patensi Arteri Radialis Selama Kompresi dengan Metode Pengamatan Klinik pada Subjek Penelitian $(n=20)$

\begin{tabular}{|c|c|c|}
\hline \multirow[t]{2}{*}{ Waktu Penilaian } & Frekuensi & Persentase \\
\hline & (f) & $(\%)$ \\
\hline \multicolumn{3}{|l|}{ Pre Prosedur Kateterisasi } \\
\hline Positif & 20 & 100,0 \\
\hline Negatif & 0 & 0,0 \\
\hline \multicolumn{3}{|c|}{$\begin{array}{l}\text { Selama Pemakaian Alat kompresi } \\
(\text { stepty- } p)\end{array}$} \\
\hline \multicolumn{3}{|l|}{15 (menit) } \\
\hline Positif & 19 & 95,0 \\
\hline Negatif & 1 & 5,0 \\
\hline \multicolumn{3}{|l|}{30 (menit) } \\
\hline Positif & 20 & 90,0 \\
\hline Negatif & 2 & 10,0 \\
\hline \multicolumn{3}{|l|}{ 45(menit) } \\
\hline Positif & 20 & 100,0 \\
\hline Negatif & 2 & 0,0 \\
\hline \multicolumn{3}{|l|}{60 (menit) } \\
\hline Positif & 20 & 100,0 \\
\hline Negatif & 2 & 0,0 \\
\hline \multicolumn{3}{|l|}{90 (menit) } \\
\hline Positif & 19 & 95,0 \\
\hline Negatif & 1 & 5,0 \\
\hline \multicolumn{3}{|l|}{120 (menit) } \\
\hline Positif & 19 & 95,0 \\
\hline Negatif & 1 & 5,0 \\
\hline \multicolumn{3}{|l|}{180 (menit) } \\
\hline Positif & 18 & 90,0 \\
\hline Negatif & 2 & 10,0 \\
\hline
\end{tabular}

hilangnya sensasi rasa seperti kesemutan atau baal, penilaian capillary refill lebih dari dua detik penekanan pada kuku ibu jari, dan penilaian perabaan pulsasi arteri radialis.

Hasil penelitian menunjukkan bahwa kondisi arteri radialis subjek penelitian pada praprosedur kateterisasi jantung semuanya $(100 \%)$ dalam kondisi paten, hal ini berarti bahwa tidak ada satu orang pun dari responden yang mengalami gangguan keutuhan arteri radialis selama praprosedur kateterisasi jantung berdasarkan penilaian dengan metode pengamatan klinik.

Hasil penilaian selama proses kompresi berlangsung yaitu selama tiga jam, hasil penelitian ini menunjukkan adanya gangguan keutuhan arteri radialis hanya pada sebagian kecil responden, berkisar pada 5-10\% responden. Gangguan keutuhan arteri radialis selama periode kompresi ini sudah terlihat sejak menit ke-15 pada satu orang responden, namun terjadi perubahan pada menit ke-30 hingga ke-60 selama pemantauan dimana terlihat tidak ada satu orang pun responden yang mengalami gangguan keutuhan arteri radialis. Gangguan keutuhan arteri radialis kembali terlihat pada menit ke-90 hingga ke180 (tiga jam), cenderung meningkat pada akhir proses kompresi menjadi dua responden $(10 \%)$. Berdasarkan hasil penelitian ini, dapat 
Nurhusna: Metode Berbeau Test dalam Menilai Keutuhan Arteri Radialis

Tabel 4 Perbandingan Metode Barbeau Test dan Metode Pengamatan Klinik dalam Menilai Keutuhan Arteri Radialis berdasarkan Waktu Pengukuran Selama Kompresi.

\begin{tabular}{|c|c|c|c|c|c|}
\hline \multirow{2}{*}{ Waktu Pengukuran } & \multicolumn{2}{|c|}{ Barbeau Test } & \multicolumn{2}{|c|}{$\begin{array}{l}\text { Pengamatan } \\
\text { Klinik }\end{array}$} & \multirow[t]{2}{*}{$\begin{array}{c}P \\
\text { Uji Mcnemar }\end{array}$} \\
\hline & Positif & Negatif & Positif & Negatif & \\
\hline 15 Menit & 13 & 7 & 19 & 1 & 0,031 \\
\hline 30 Menit & 14 & 6 & 20 & 0 & 0,031 \\
\hline 45 Menit & 16 & 4 & 20 & 0 & 0,125 \\
\hline 60 Menit & 16 & 4 & 20 & 0 & 0,125 \\
\hline 90 Menit & 18 & 2 & 19 & 1 & 1,000 \\
\hline 120 Menit & 16 & 4 & 19 & 1 & 0,250 \\
\hline 180 Menit & 5 & 15 & 18 & 2 & 0,375 \\
\hline P Uji Cochran & & 0,386 & & 0,526 & \\
\hline
\end{tabular}

disimpulkan bahwa gangguan keutuhan arteri radialis pada responden berdasarkan penilaian dengan metode pengamatan klinik hanya terjadi pada sebagian kecil responden pada awal proses kompresi dan di akhir proses kompresi sebelum alat kompresi dilepaskan. Gangguan keutuhan cenderung meningkat di akhir proses kompresi.

3). Perbandingan Metode Barbeau Test dan Metode Pengamatan Klinik dalam Menilai Keutuhan Arteri Radialis pada Subjek Penelitian

Analisis perbandingan metode Barbeau test dan metode pengamatan klinik dalam menilai keutuhan arteri radialis berdasarkan uji statistik McNemar disajikan pada tabel 4.

Pada tabel 4 analisis bivariat perbandingan metode Barbeau test dan metode pengamatan klinik dalam menilai keutuhan arteri radialis selama waktu kompresi (3 jam) dengan alat stepty- $p$ berdasarkan perhitungan statistik melalui uji McNemar didapatkan hasil nilai $p$ pada pengukuran di menit ke-15 dan ke-30 $(p=0.031)$, dengan tingkat signifikansi $95 \%$ hasil penelitian ini menunjukkan nilai $p<0.05$, sehingga disimpulkan adanya perbedaan yang signifikan dari penilaian keutuhan arteri radialis menggunakan metode Barbeau test dengan metode pengamatan klinik pada menit ke-15 dan ke-30.

Pada pengukuran dimenit ke-45 hingga akhir masa kompresi (3 jam) diketahui nilai $p>0.05$ menunjukkan tidak adanya perbedaan antara metode Barbeau test dan metode pengamatan klinik dalam menilai keutuhan arteri radialis pada pengukuran di menit ke-45 hingga akhir proses kompresi (3 jam). Meskipun secara persentase terjadinya gangguan terlihat adanya perbedaan, dimana metode Barbeau test mampu menilai dengan persentase yang lebih banyak dibanding pengamatan klinik, sehingga disimpulkan bahwa metode Barbeau test mampu secara objektif menilai gangguan keutuhan arteri radialis selama proses kompresi lebih cepat dengan persentase kejadian yang lebih besar dibanding metode pengamatan klinik terutama pada menit awal ke-15 dan ke-30. Menit ke-45 hingga akhir periode kompresi kedua metode dapat digunakan untuk menilai gangguan keutuhan arteri radialis selama proses kompresi dalam penelitian ini.

\section{Pembahasan}

Hasil studi ini menunjukkan bahwa sebagian besar subjek penelitian adalah laki-laki (85\%) dan mayoritas berada pada usia lanjut (65\%). Hubungan antara jenis kelamin dengan terjadinya oklusi arteri radialis (RAO) berdasarkan hasil uji statistik menunjukkan tidak adanya hubungan $(p=0.07)$, begitu pula dengan variabel usia pada penelitian ini $(p=0.67)$. Uhleman, dkk. (2012) dalam penelitiannya menyebutkan bahwa pasien yang berusia muda dan jenis kelamin wanita memiliki risiko lebih tinggi untuk terjadinya oklusi arteri radialis, sedangkan usia lanjut 
Nurhusna: Metode Berbeau Test dalam Menilai Keutuhan Arteri Radialis

merupakan salah satu prediktor terjadinya RAO. Ketiga faktor ini berkaitan dengan aktivitas rangsangan saraf simpatis yang sangat kompleks terhadap arteri radialis yang merangsang untuk terjadinya peningkatan spasme vaskular. Di samping itu, temuan ini mungkin berkaitan dengan rata-rata diameter arteri radialis pada wanita berukuran lebih kecil.

Hasil penelitian ini juga menunjukkan bahwa sebagian besar responden memiliki indeks massa tubuh (IMT) yang normal (45\%), hanya terdapat sebagian kecil $(20 \%)$ yang mengalami obesitas. Berkaitan dengan faktor berat badan tersebut. Wu, dkk. (1997) menyebutkan bahwa berkaitan dengan ukuran diameter arteri radialis yang juga dipengaruhi oleh ukuran tubuh (body size) yang berkaitan dengan berat badan, maka pasien yang memiliki berat badan rendah memiliki risiko yang lebih dalam terjadinya RAO, begitupun pada pasien dengan berat badan yang obesitas. Kaitan antara faktor ini dengan terjadinya RAO dihubungkan dengan kondisi adanya perubahan vaskular (intimal hyperplasia dan penyempitan lumen) dan aterosklerosis yang memengaruhi struktur dari arteri radialis. Di samping itu, obesitas dapat dikaitkan dengan prediktor lain dari kejadian RAO yaitu proses kanulasi kateter yang dilakukan secara berulang selama prosedur kateterisasi jantung, di mana pasien dengan kondisi obesitas memiliki tingkat kesulitan yang tinggi dalam proses kanulasi kateter melalui akses arteri radialis. Sehingga dibutuhkan tenaga yang benar-benar terlatih.

Berkaitan dengan jenis-jenis antikoagulan yang digunakan selama prosedur tindakan kateterisasi jantung, hasil dari penelitian ini menunjukkan bahwa antikoagulan jenis heparin lebih banyak digunakan selama prosedur $(70 \%)$, dibandingkan penggunaan heparin plus. Terapi heparin plus yaitu pemberian heparin dengan golongan berat molekul rendah yaitu enoxevarin (lovenox) dengan tambahan dari jenis antikoagulan lain seperti plavix (clovidogrel). Hasil dari penelitian ini menunjukkan bahwa tidak ada subjek penelitian yang mengalami gangguan keutuhan arteri radialis dengan penggunaan heparin plus, hasil penelitian ini juga menjelaskan bahwa semua responden yang mengalami gangguan adalah dengan penggunaan heparin saja.

Hasil ini menunjukkan bahwa pemberian antikoagulan dalam prosedur kateterisasi jantung trans radial sangat berperan untuk terjadinya RAO terutama heparin. Hasil beberapa penelitian menunjukkan peranan penting dari antikoagulan heparin selama prosedur kateterisasi jantung trans radial dalam pencegahan insiden RAO, namun penggunaan heparin akan lebih bermakna apabila seimbang dengan penggunaan teknik kompresi yang tepat. Hal ini dijelaskan dari hasil sebuah studi secara acak yang membandingkan dari penggunaan heparin dengan dosis rendah (dosis rendah heparin yaitu 2000 IU) dengan heparin dosis standar (dosis standar yaitu 5000 IU) selama prosedur kateterisasi jantung trans radial. Hasil penelitian ini menunjukkan bahwa tidak adanya perbedaan yang bermakna terhadap insiden terjadinya RAO, disimpulkan bahwa penggunaan heparin dengan dosis rendah (2000 IU) terbukti aman dan sebanding dengan heparin sesuai standar dosis (5000 IU) (Pancholy \& Patel, 2012).

Hasil penelitian menggunakan metode Barbeau test maupun menggunakan metode pengamatan klinik menilai adanya gangguan keutuhan arteri radialis selama proses kompresi. Berdasarkan penilaian dengan kedua metode tersebut gangguan keutuhan arteri radialis ini telah terjadi sejak awal proses kompresi menggunakan stepty- $p$, yaitu pada 15 menit pertama setelah pemasangan alat kompresi dan terus berlanjut hingga akhir proses kompresi. Terlihat adanya fluktuasi persentase kejadian, dimana gangguan keutuhan arteri radialis terlihat lebih tinggi pada awal proses kompresi, kemudian cenderung menurun hingga akhir periode kompresi. Gangguan keutuhan aliran darah di arteri radialis yang terjadi sejak awal proses kompresi ini dapat disebabkan karena pemakaian alat kompresi yang terlalu ketat sehingga menghambat aliran darah di arteri radialis dan merangsang terjadinya trombosis. Katowycz \& Dzavik (2012) dalam penelitiannya mengatakan bahwa kehilangan keutuhan arteri radialis secara akut pascakateterisasi jantung berhubungan dengan terjadinya trombosis. Pemicu terjadinya trombosis ini dapat disebabkan karena trauma penetrasi atau trauma akibat 
Nurhusna: Metode Berbeau Test dalam Menilai Keutuhan Arteri Radialis

penekanan yang terlalu agresif atau disebut sebagai 'hyperextension compression' di arteri radialis selama proses hemostasis (McNamara, Butler, Sanders, \& Pederson, 1998; Isenberg, 2000; Lee, Miller \& Laitung. 1995). Kompresi eksternal pada arteri radialis ini mengakibatkan terjadinya penurunan aliran darah anterograde dan merangsang pembentukan koagulasi darah yang terus berlanjut hingga terbentuknya arterial thrombotic occlusion atau sumbatan trombus di arteri (Brancati, dkk., 2012; Chitte, Veltri, $\&$ Thoma, 2003).

Hasil penelitian didapatkan bahwa penilaian keutuhan arteri radialis selama proses kompresi berdasarkan metode pengamatan tanda dan gejalaklinik didapatkan hasil sebagai berikut : terganggunya keutuhan arteri selama proses kompresi terjadi hanya pada sebagian kecil subjek penelitian (10\%), dengan persentase kejadiannya bervariasi selama tiga jam pemantauan. Tanda dan gejala klinik yang muncul seperti perubahan warna pada kulit telapak tangan terlihat lebih pucat (avaskular), kebiruan (sianosis), disertai dengan keluhan rasa kesemutan atau baal (parastesia) pada lengan. Terjadinya perubahan warna kulit menjadi avaskular, sianosis, dan perubahan suhu di tangan yang menjadi lebih dingin menunjukkan gangguan perfusi akibat terjadinya penurunan aliran darah arteri (Namdari, Park, Weiss, \& Carney, 2008).

Hasil beberapa penelitian menunjukkan persentase kejadian gangguan keutuhan arteri radialis dengan gejala seperti ini terjadi sekitar $25 \%$ hingga $33 \%$, namun gejala iskemik yang ditandai dengan nyeri pada tangan pascaprosedur sangat jarang dilaporkan, hanya berkisar satu dari 500 kasus (Sfeir, dkk., 1996; Cederholm, Sorensen \& Carlsson. 1996 ; Slogoff, dkk., 1993; Brancati, dkk., 2012), begitupula pada penelitian ini tidak ada subjek penelitian yang mengeluhkan nyeri. Apabila gejala ini muncul terutama dengan derajat nyeri berat diduga akan menyebabkan komplikasi iskemik yang mengancam pada penderita (Brancati, dkk., 2012).

Hasil dari penelitian pada satu jam pertama pemantauan, gangguan keutuhan terjadi hanya $5 \%$, waktu terjadinya gangguan hanya pada 15 menit awal setelah alat kompresi dipasang dan tidak ditemukan lagi pada menit berikutnya. Setelah satu jam, gangguan keutuhan kembali terlihat pada satu orang subjek penelitian (5\%), gangguan terus terjadi hingga akhir jam kedua setelah alat kompresi terpasang. Setelah dua jam atau pada jam ketiga pemantauan sebelum alat kompresi dilepas, gangguan keutuhan terlihat meningkat yang terjadi pada dua orang $(10 \%)$ subjek penelitian. Adanya variasi gangguan yang hilang dan timbul selama proses kompresi ini dapat disebabkan karena kuatnya pengaruh dual sirkulasi antara arteri ulnaris dan radialis dalam menghantarkan sirkulasi darah ke telapak tangan. Hal tersebut membentuk suatu hubungan kolateral yang akan berkompensasi dengan meningkatkan aliran darah arteri apabila salah satu arteri ini mengalami oklusi atau penyumbatan, kondisi ini cenderung mengakibatkan kasus gangguan keutuhan terlihat asimtomatis, tidak disadari oleh petugas maupun oleh pasien sendiri (Katowycz \& Dzavik, 2012). Namun apabila pasien memiliki indikasi untuk mengalami masalah oklusi seperti pasien dengan penyakit peripheral desease dan lainya ataupun tidak memiliki dual sirkulasi kolateral yang cukup baik, maka gejala klinik gangguan keutuhan dapat saja muncul (Whelan, 1992).

Metode Barbeau test menggunakan gelombang plethysmography dan pulse oxymetry telah digunakan dalam menilai kemampuan dual sirkulasi radial dan ulna. Metode ini dilakukan untuk mengetahui keadekuatan sirkulasi kolateral antara kedua arteri ini (Barbeau, dkk., 2004). Metode ini terbukti dapat digunakan untuk mendeteksi adanya oklusi di arteri radialis post prosedur kateterisasi jantung trans radial sehingga metode ini dapat direkomendasikan untuk digunakan selama post prosedur tindakan kateterisasi jantung (Brancati, dkk., 2012; Pancholy \& Patel, 2012). Pada praprosedur kateterisasi jantung, metode ini dipakai dalam menyeleksi pasien yang benar-benar tepat untuk menggunakan akses radial dalam prosedur kateterisasi jantung (Barbeau, dkk., 2004).

Penilaian dengan metode Barbeau test mendapatkan hasil bahwa gangguan keutuhan arteri radialis ditemukan pada $25 \%$ subjek penelitian. Gangguan keutuhan terdeteksi sejak awal proses kompresi (15 
Nurhusna: Metode Berbeau Test dalam Menilai Keutuhan Arteri Radialis

menit pertama setelah pemasangan alat kompresi stepty- $p$ ) hingga akhir kompresi (3 jam). Presentase kejadian cenderung tinggi pada satu jam pertama terutama 15 menit awal (35\%), menurun hingga 10\% diakhir jam kedua kompresi dan kembali meningkat namun tidak setinggi di awal pada akhir jam ketiga (25\%) sebelum alat kompresi dilepas.

Dilihat pada penelitian ini, gangguan keutuhan arteri radialis dinilai berdasarkan gambaran gelombang plethysmography yang hilang juga tidak adanya saturasi oksigen ketika melakukan kompresi ulnaris disaat alat kompresi di arteri radialis tetap terpasang. Ketiadaan gelombang plethysmography juga saturasi oksigen menunjukkan telah terjadinya hambatan aliran daranh di arteri radialis dan ini dapat diindikasikan sebagai complete occlusion (Brancati, dkk., 2012). Adanya fluktuasi persentase kejadian selama proses kompresi menunjukkan peran mekanisme kompensasi dari sirkulasi kolateral yang meningkatkan aliran ketika terjadinya oklusi. Hasil penelitian ini selaras dengan temuan penelitian yang dilakukan oleh Sanmartin, dkk. (2005) menggunakan metode Barbeau test untuk penilaian keutuhan arteri radialis selama kompresi menggunakan bahan balutan luka biasa yang dimodifikasi. Hasilnya menunjukkan bahwa gangguan keutuhan terlihat tinggi pada awal kompresi $(62 \%)$, sedikit menurun setelah dua jam pemasangan $(58 \%)$ dan pada akhir kompresi sebelum alat kompresi dilepas (54\%). Hasil penelitian ini menyimpulkan bahwa occlusive compression atau kompresi yang terlalu kuat menjadi prediktor ketiga yang dapat menyebabkan RAO, sehingga diperlukan pemantauan yang ketat selama proses kompresi guna memelihara arterial blood flow arteri radialis supaya tetap paten. Metode Barbeau test adalah metode yang objektif untuk digunakan selama pemantauan tersebut (Sanmartin, dkk., 2005).

Hasil dari analisis statistik pada penelitian ini menunjukkan bahwa metode Barbeau test mampu menilai terjadinya gangguan keutuhan arteri radialis pada subjek penelitian lebih banyak dibanding metode pengamatan klinik selama proses kompresi. Perbandingan persentase penilaian terlihat mencolok di 15 menit awal yaitu ( $35 \%$ vs $5 \%$, nilai $p=0.031)$, 30 menit ( $30 \%$ vs $0 \%$, nilai $p=0.031)$.
Hasil uji analisis statistik ini menunjukkan adanya perbedaan yang bermakna antara metode Barbeau test dan metode pengamatan klinik dalam menilai keutuhan arteri radialis selama proses kompresi di menit ke-15 dan ke-30 dengan nilai $p<0.05$. Sebaliknya hasil uji analisis statistik menunjukkan tidak terdapat perbedaan yang bermakna antara kedua metode pada pengukuran dimenit ke45 hingga tiga jam selama proses kompresi dengan nilai $p>0.05$.

Metode Barbeau test sangat baik digunakan dalam menilai keutuhan arteri radialis pada menit-menit awal proses kompresi, karena mampu mengenali gangguan keutuhan lebih cepat dan banyak dibandingkan metode pengamatan, karena pada awal proses oklusi arteri radialis mendapatkan mekanisme kompensasi dari sirkulasi kolateral. Kondisi ini yang menyamarkan gejala klinik tidak terlihat (asimtomatis). Seperti penelitian yang dilakukan Bertrand, dkk. (2010) menemukan bahwa kejadian RAO yang tidak terdeteksi sebelum pasien pulang lebih dari 50\%. Penelitian serupa yang dilakukan oleh Uhleman, dkk. (2012) terhadap 455 pasien yang menjalani kateterisasi jantung trans radial, dimana hasil penelitiannya menemukan bahwa terdapat 22 orang pasien yang terdeteksi mengalami oklusi arteri radialis namun tidak menunjukkan gejala klinik yang bermakna, dimana denyut nadi radial masih teraba. Hasil penelitian ini menunjukkan adanya peranan sirkulasi kolateral yang ada di telapak tangan dalam memfasilitasi sementara kebutuhan sirkulasi darah arteri radial yang mengalami oklusi. (Pancholy, 2009).

Keterbatasan yang peneliti temukan, yaitu: pertama, karena desain penelitian ini adalah studi deskriptif analisis dan tidak melakukan pengambilan sampel acak pada penelitian. Sehingga memunculkan kemungkinan untuk terjadinya bias dalam penyeleksian sampel penelitian. Kedua, karena adanya keterbatasan peneliti dalam mendokumentasikan datadata penting terkait penelitian ini terutama selama proses prosedur kateterisasi jantung dilakukan di ruang tindakan angiografi, data seperti frekuensi penusukan kateter dan keahlian dari tenaga medis yang melakukan. Ketiga, karena peneliti tidak dapat melakukan pemeriksaan struktur anatomi arteri radialis 
Nurhusna: Metode Berbeau Test dalam Menilai Patensi Arteri Radialis

di awal prosedur menggunakan alat doppler dikarenakan keterbatasan peneliti untuk menyediakan alat di samping prosedur ini memang tidak menjadi standar prosedur rutin di tempat penelitian.

\section{Simpulan}

Hasil penelitian ini dapat disimpulkan bahwa metode Berbeau test dianggap lebih baik untuk digunakan daripada metode pengamatan klinik dalam menilai keutuhan arteri radialis. Hasil dari metode Berbeau test lebih baik dalam menilai keutuhan arteri radialis di menit ke-15 dan menit ke-30, akan tetapi di menit ke-45 tidak ada perbedaan penilaian keutuhan arteri radialis antara menggunakan metode Berbeau test dan pengamatan klinik. Hasil penelitian ini menunjukkan bahwa perawat harus terus melakukan monitoring keutuhan arteri radialis.

\section{Daftar Pustaka}

Achouh, P., Isselmou, K. O., Boutekadjirt, R., D’Alessandro, C., Pagny, J. Y., Fouquet, R., ... Acar, C. (2012). Reappraisal of a 20-year experience with the radial artery as a conduit for coronary bypass grafting. European Journal of Cardio-Thoracic Surgery, 41(1), 87-92.

Ariawan, I. (1998). Besar dan metode sampel ada penelitian kesehatan. jurusan biostatistik dan kependudukan. Fakultas Kesehatan Masyarakat, Universitas Indonesia.

Barbeau, G. R., Arsenault, F., Dugas, L., Simard, S., \& Lariviere, M. M. (2004). Evaluation of the ulnopalmar arterial arches with pulse oxymetry and plethysmography: Comparison with the Allen's test In 1010 Patiens. American Heart Journal, 147(3), 689-493.

Berry, C. Kelly, J., Cobbe, S. M., \& Eteiba, H. (2004). Comparison of femoral bleeding complications after coronary angiography versus percutaneous coronary intervention. The American Journal of Cardiology, 94(3), 361-363.
Biancari, F., D'Andrea, V., Di Marco, C., Savino, G., Tiozzo, V., \& Catania, A. (2010). Meta-analysis of randomized trials on the efficacy of vascular closure devices after diagnostic angiography and angioplasty. American Heart Journal, 159(4), 518-531.

Brancati, M. F., Burzotta, F., Colucia, V., \& Trani, C. (2012). The occurrence of radial artery occlusion following catheterization. Expert Reviews Cardiovascular Therapy, 10, 1-8.

Cederholm, Sorensen \& Carlsson. (1996). Thrombosis following percutaneous radial artery cannulation. Acta Anasthesiol Scand, $30,227-230$.

Chitte, S. A., Veltri, K \& Thoma, A., (2003). Ischemia of the hand secondary to radial artery thrombosis. Canadian Journal of Plastic Surgery, 11, 145-148.

Cooper, C. J., El-Shiekh, R. A., Cohen, D. J., Blaesing, L., Buirket, M. W., Basu, A., \& Moore, J. A. (1999). Effect of transradial access on quality of life and cost of cardiac catheterization : A randomized comparison. American Heart Journal, 138(3), 430-436.

Falk, E., Shah, P. K., \& Fuster, V. (2005). Coronary plaque disruption. Circulation. 92, 657-671.

Gilchrist, I. C. (2009). Laissez-faire hemostasis and transradial injuries. Catheterization Cardiovascular Intervention. 73(4), 473-474.

Isenberg, J.S. (2000). Spontaneous exercise induced thrombosis of the radial artery : A case report and literature review. Annual of Plastic Surgery, 44, 79-81.

Katowycz, M. A., \& Dzavik, V. (2012). Radial artery patency after transradial catheterization. Circulation : Cardiovascular Intervention, 5, 127-133.

Lee, K. L., Miller, J. G., \& Laitung, G., (1995). Hand ischemia following radial rrtery cannulation. Journal Of Hand Surgery, 20, 493-495. 
McNamara, M. G., Butler, T. E., Sanders, W. E., \& Pederson, W. C. (1998). Ischaemia of the index finger and thumb secondary to thrombosis of the radial artery in the anatomical snuffox. Journal of Hand Surgery (British and European Volume), 23(1), 28-32.

Mitinach \& Hollinger. (2005). Cardiac catheterization and other radiographic examination. Lippincot William and Wilkins, 7, 112:135.

Nagai, S., Abe, S., Sato, T., Hozawa, K., Yuki, K., Hanashima, K., \& Tomoike, H. (1999). Ultrasonic aassessment of vascular complications in coronary angiography and angioplasty after transradial approach. American Journal Cardiology, 83, 180-186.

Namdari, S., Park, M. J., Weiss, A. P. C., \& Carney, W. I. (2008). Chronic hand ischemia treated with radial artery ballon angioplasty: Case report. The Journal Hand Surgery, 33(4), 551-554.

Pancholy, S \& Patel. (2012). Effect of duration of hemostatic compression on radial artery occlusion after transradial access. Catheterization and Cardiovascular Intervention, 79, 78-81.

Pancholy, S. (2009). Impact of two different hemostatic devices on radial artery outcomes after transradial catheterization. Journal of Invasive Cardiology, 21 (3), 101-104.

Sanmartin, M., Gomez, M., Rumoroso, J. R., Sadaba, M., Martinez, M., Baz, J. A., \& Iniguez, A. (2007). Interruption of blood flow during compression and radial artery occlusion after transradial catheterization. Catheterization and Cardiovascular Intervention, 70(2), 185-189.

Sfeir, R., Khoury, S., Khoury, G., Rustum, J., \& Ghabash, M. (1996). Ischemia of the hand after radial artery monitoring. Cardiovascular Surgery, 4, 456-458.

Slogoff,S., Keats, A.S., \& Arlund. (1993). On the safety of radial artery cannulation. Anesthesiology, 59, 42-47.
Spaulding, C., Lefevre, T., Funck, F., Thebault, B., Chauveau, M., Hamda, K. B., ... Weber, S. (1996). Left radial approach for coronary angiography: Result of a prospective study. Catheterization Cardiovascular Diagnosis Journal, 39 (4), 364-370.

Stella, P. R., Kiemeneij, F., Laarman, G. J., Odekerken, D., Slagboom, T., \& Van der Wieken, R. (1997). Incidence and outcome of radial artery occlusion following transradial artery coronary angioplasty. Catheterization Cardiovascular Diagnosis, 40(2), 156-158.

Tse., T. S., Lam, K. K. H., Tsui, K. L., Chan, C. K., Leung, G. T. C., Choi, M. C., Ko, W. C., ... Li, S. K. (2006). Feasibility of transradial coronary angiography and angioplasty in Chinese patients. Hong Kong Med J, 12(2), 108-114.

Uhlemann, M., Mobius-Winkler, S., Mende, M., Eitel, I., Fuernau, G., Sandri, M., ... Gielen, S. (2012) .The leipzig prospective vascular ultrasound registry in radial artery catheterization : Impact of sheath size on vascular complications. JACC: Cardiovaskuler Interventions, 5(1), 36-43.

Whelan, T. (1992). Management of vascular disease of the upper extremity. Journal Of Surgical Clinical North American, 62, 373389.

Wu, C. J., Lo, P. H., Chang, K. C., Fu, M., Lau, K. W., \& Hung, J. S. (1997). Transradial coronary angiography and angioplasty in chinese patient. Catheterization and Cardiovascular Diagnosis, 40(2), 159-163.

Yonetsu, T., Kakuta, T., Lee, T., Takayama, K., Kakita, K., Iwamoto, T., .... Isobe, M. (2010). Assessment of acute injuries and chronic intimal thickening of the radial artery after transradial coronary intervention by opticahal coherence tomography. European Heart Journal, ehq102.

Yoo, B. S., Yoon, J., Ko, J. Y., Kim, J. Y., Lee, S. H., Hwang, S. O., \& Choe, K. H. 2005. Anatomical consideration of the radial artery for transradial coronary procedures: 
Nurhusna: Metode Berbeau Test dalam Menilai Patensi Arteri Radialis

Arteries diameter, branching anomaly and vessel tortuosity. International Journal of Cardiology. 101(3), 421-427.

Zhou, Y. J., Zhao, Y. X., Cao, Z., Fu, X.
H., Nie, B., Liu,Y. Y., \& Jia, D. A. (2007). Incidence and risk factors of acute radial artery occlusion following transradial percutaneous coronary intervention. Zhonghua Yi Xue Za Zhi, 87(22), 1531-1534. 